\title{
Perancangan Boiler untuk Proses Sterilisasi pada Baglog Jamur Tiram
}

\author{
Ronald Akbar $^{1, a)}$, Agus Sukandi ${ }^{2, b)}$, M. Kurniadi Rasyid ${ }^{1, c)}$ \\ ${ }^{1}$ Program Studi Teknik Mesin ITI, \\ Jl. Raya Puspiptek Serpong, Tangerang Selatan-Banten, Indonesia, 15320 \\ ${ }^{2}$ Jurusan Teknik Mesin Politeknik Negeri Jakarta, \\ Jl. Prof. Dr. G.A Siwabessy, Kampus Baru UI Depok, 16424 \\ a) ronaldakbar28x1@gmail, b) agus.sukandi@mesin.pnj.ac.id, ${ }^{c)}$ kurniadirasyid@ gmail.com
}

\begin{abstract}
Abstrak
Pada proses pembuatan baglog jamur tiram, boiler digunakan untuk proses sterilisasi baglog sebelum bibit jamur tiram ditanam. Perancangan boiler ini bertujuan untuk mengurangi permasalahan pada proses sterilisasi, yaitu ketidakstabilan temperatur yang menyebabkan organisme pengganggu bibit jamur tiram tidak semuanya mati. Sehingga dengan perancangan boiler ini diharapkan membantu untuk menghasilkan jamur tiram dengan kualitas yang baik dan mengurangi kegalalan panen. Tahapan yang dilakukan dalam perancangan ini adalah menghitung konstruksi boiler sesuai dengan standar ASME BPVC (American Society of Mechanical Engineers Boiler and Pressure Vessel Code), dengan menggunakan material SA 53 Grade B dan SA 285 Grade C. Kemudian dilanjutkan dengan proses analisis statis model boiler menggunakan software Pro Engineer Wildfire 4.0, yang hasilnya adalah berupa tegangan Von Mises dan displacement. Hasil analisa menyatakan bahwa tegangan Von Mises yang terjadi sebesar 2,056 x $10^{8} \mathrm{~N} / \mathrm{m}^{2}$, dibawah tegangan yang diizinkan yaitu sebesar $4,15 \times 10^{8} \mathrm{~N} / \mathrm{m}^{2}$. Maka dengan hasil tersebut desain dapat dikatakan aman.
\end{abstract}

Kata kunci: $A S M E P B V C$, baglog, boiler, perancangan

\begin{abstract}
In the process of making the baglog for oyster mushrooms, boilers are used for the baglog sterilization process before the seeds of the oyster mushrooms are planted. The design of the boiler aims to reduce the problems in the sterilization process, which is the temperature instability that causes the disturbing organisms are not die entirely. So in conjunction of this boiler design, the oyster mushrooms can be produced with good quality and the crop failure reduced. The steps in this design are calculating boiler construction according to the ASME BPVC (American Society of Mechanical Engineers Boilers and Pressure Vessel Codes) standard, using the material of SA 53 Grade B and SA 285 Grade C. Then the boiler's model is processed with static analysis using Pro Engineer Wildfire 4.0 software which yield Von Mises stress and displacement. The results analysis state that the Von Mises stress is $2.056 \times 10^{8} \mathrm{~N} / \mathrm{m}^{2}$, or below the allowable stress of $4.15 \times 10^{8} \mathrm{~N} / \mathrm{m}^{2}$. So with these results the design is considered to be safe.
\end{abstract}

Keywords: ASME PBVC, baglog, boiler, design,

\section{PENDAHULUAN}

\section{A. Latar Belakang}

Industri baglog jamur tiram merupakan salah satu industri pertanian yang perlu dikembangkan dalam peralatan produksinya. Hal ini dikarenakan prospek pasarnya yang bagus dan memiliki potensi ekonomi yang tinggi dengan segmen pasar yang jelas. Pada segmen restoran dan hotel, kebutuhan akan jamur tiram cukup tinggi. Jadi dibutuhkan pasokan jamur tiram yang banyak dan cepat. Adanya industri baglog jamur tiram ini dapat memenuhi permintaan pasar tersebut karena proses penanamanya yang sederhana dengan hasil panen yang cukup banyak dan cepat.

Namun terdapat masalah yang sering dihadapi oleh petani baglog, yaitu proses sterilisasi dari baglog yang tidak baik. Baglog adalah sebuah media tumbuh dari jamur tiram. Sebelum proses pemasukkan bibit jamur, baglog harus melewati proses sterilisasi berupa pemanasan dengan suhu tinggi yang bertujuan untuk mematikan berbagai patogen dan mikroba lain pada media tumbuh tersebut. Biasanya para petani hanya menggunakan peralatan seadanya untuk melakukan proses sterilisasi ini, sebagai contoh adalah memodifikasi drum bekas untuk dijadikan alat pemanas. Hal tersebut kurang baik karena suhu pemanasan yang tidak teratur sehingga kualitas dari jamur tiram akan menurun atau lebih parahnya lagi adalah kegagalan panen.

Perkembangan ilmu teknologi saat ini dapat mendukung alat produksi pada industri baglog jamur tiram. Salah satunya teknologi dalam bidang konversi energi yang memunculkan banyak ide kreatif untuk memanfaatkannya dalam dunia industri. Berdasarkan hal tersebut dilakukan sebuah penelitian berupa perancangan suatu boiler atau ketel uap yang sesuai dengan standar yang ada sehingga dapat menaikkan hasil panen dan kualitas dari suatu industi baglog jamur tiram.

\section{B. Rumusan Masalah}

Permasalahan dalam industri baglog secara umum adalah pada proses sterilisasi atau pemanasan pada 
baglog. Banyak hasil panen jamur tiram yang buruk kualitasnya bahkan terjadi kegagalan akibat proses sterilisasi yang kurang baik pada baglog. Sedangakan Permasalahan dalam industri baglog secara khusus adalah penggunaan alat pemanas pada proses sterilisasi yang kurang memadai, oleh karena itu dibutuhkan suatu alat pemanas berupa boiler yang sesuai dengan standar sehingga dapat dihasilkan jamur tiram dengan kualitas yang baik.

\section{Tujuan Penulisan}

Tujuan penulisan dari tugas akhir ini adalah:

a. Merancang sebuah boiler untuk proses sterilisasi pada baglog jamur tiram sesuai dengan standar yang ada, yaitu standar ASME (American Society of Mechanical Engineers) Boiler and Pressure Vessel Code (BPVC).

b. Mengurangi permasalahan pada industri baglog yaitu pada proses sterilisasi. Sehingga dapat dihasilkan jamur tiram dengan kualitas yang bagus sekaligus dapat mengurangi kerugian petani baglog akibat kegagalan panen.

\section{LANDASAN TEORI}

\section{A. Baglog Jamur}

Baglog adalah media siap panen yang terdiri dari campuran antara serbuk gergaji, bekatul serta gamping yang diaduk bersamaan dengan air dan dimasukkan kedalam plastik tahan panas polypropylene (PP) [1]. Bahan utama yang bisa digunakan dalam media tanam jamur tiram diantaranya adalah serbuk gergaji, jerami padi, sekam, sisa kertas, serta bahan lainnya seperti ampas tebu, ampas aren, dan sabut kelapa. Selain bahanbahan tersebut biasanya masih ditambahkan bahan lain seperti bekatul, bungkil biji kapok, kotoran ayam, gypsum dan kapur [2]. Contoh dari baglog jamur tiram ditunjukkan pada Gambar 1.

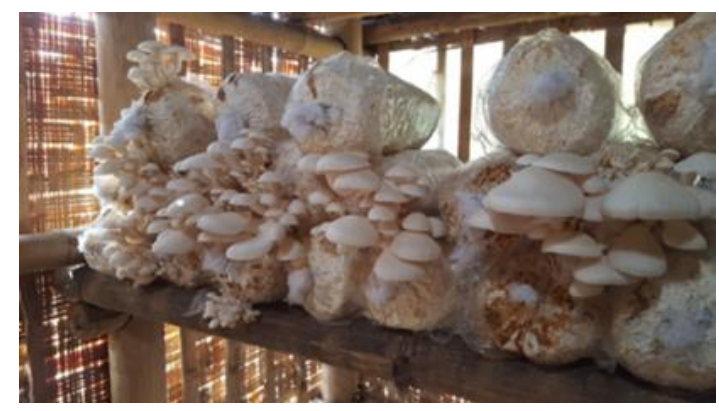

Gambar 1. Baglog Jamur

\section{B. Boiler}

Boiler merupakan mesin kalor (thermal engineering) yang mentransfer energi-energi kimia yaitu energi otomis menjadi kerja (usaha) [3]. Boiler atau ketel uap adalah suatu alat berbentuk bejana tertutup yang terbuat dari baja yang berfungsi untuk mentransfer panas yang dihasilkan dari pembakaran bahan bakar ke air yang menjadi uap atau steam yang berguna. Uap ini digunakan untuk proses-proses industri, penggerak, pemanas, dan lain-lain [4].

Boiler pada dasarnya terdiri atas drum yang tertutup ujung dan pangkalnya dan dalam perkembangannya dilengkapi dengan pipa api maupun pipa air. Boiler diklasifikasikan sebagai berikut:

a. Boiler pipa api (fire tube boiler)

Boiler jenis ini pada bagian tubenya dialiri dengan gas pembakaran dan bagian lainnya yaitu shell dialiri air yang akan diuapkan. Tube-tubenya langsung didinginkan oleh air yang melindunginya. Jumlah pass dari boiler tergantung dari jumlah laluan horizontal dari gas pembakaran diantara furnace dan pipa-pipa api. Laluan gas pembakaran pada furnace dihitung sebagai pass pertama. Boiler jenis ini banyak dipakai untuk industri pengolahan mulai skala kecil sampai skala menengah [5]. b. Boiler pipa air (water tube boiler)

Boiler jenis ini banyak dipakai untuk kebutuhan uap skala besar. Prinsip kerja dari boiler pipa air berkebalikan dengan pipa api, gas pembakaran dari furnace dilewatkan ke pipa-pipa yang berisi air yang akan diuapkan.

\section{Teori Kekuatan Material}

Dalam merancang suatu struktur, ditetapkan prosedur pemilihan suatu material yang sesuai dengan kondisi aplikasinya. Kekuatan bahan bukan kriteria satu-satunya yang harus dipertimbangkan dalam perancangan struktur. Berlawanan dengan mekanika, kekuatan bahan berkaitan dengan hubungan antara gaya luar yang bekerja dan pengaruhnya terhadap gaya dalam benda [6].

\section{Metode Elemen Hingga}

Metode elemen hingga atau dapat disebut dengan Finite Element Metode (FEM) atau Finite Element Analysis (FEA), adalah dasar pemikiran dari suatu bangunan bentuk-bentuk kompleks dengan blok-blok sederhana atau membagi objek yang kompleks ke dalam bagian-bagian kecil yang teratur. Karena sifat-sifat setiap elemen dievaluasi secara terpisah, maka adalah suatu keuntungan yang pasti bila kita dapat memasukkan sifatsifat bahan yang berbeda untuk setiap elemen [7].

\section{E. Analisis Komputer Menggunakan Pro Engineer Wildfire 4.0}

Kemajuan dalam bidang komputer saat ini sangat membantu dalam proses penyelesaian analisis, khususnya analisis kekuatan struktur. Saat ini banyak tersedia berbagai jenis perangkat lunak (software) yang digunakan untuk analisia struktur, salah satunya adalah Pro Engineer Wildfire 4.0 yang merupakan produk keluaran dari Parametric Technology Corporation (PTC). Pro Engineer merupakan pelopor perangkat lunak desain 3 dimensi yang memakai sistem parametrik. Penggunaan software ini dapat dipakai untuk menganalisis komponen baik itu kekuatan struktur dalam beban statis, analisis frekuensi bebas sampai simulasi perancangan dapat dilakukan.

\section{METODE PENELITIAN}

Perancangan tugas akhir atau skripsi ini menggunakan tiga metode, yaitu metode studi literatur, perhitungan secara manual, dan simulasi software. Metode studi literatur dilakukan dengan mencari dan mempelajari referensi dari buku literatur, jurnal, skripsi, dan website di internet yang terkait dan diperlukan dalam perancangan tugas akhir ini. Kemudian metode perhitungan secara manual diterapkan dengan menggunakan rumus-rumus 
serta standar yang telah ada dan sesuai dengan standar ASME PBVC (American Society Mechanical Engineers Boiler and Pressure Vessel Code). Langkah terakhir adalah dengan melakukan simulasi yang dilakukan dengan menggunakan salah satu perangkat lunak (software) pada komputer yaitu Pro Engineer Wildfire 4.0. Metode ini dilakukan untuk melihat dan mengamati beban-beban (load) yang terjadi pada setiap bagian dari boiler dan sebagai pembuktian dari perhitungan yang dilakukan secara manual sebelumnya. Hasil akhir dari tugas akhir ini berupa data-data dari hasil perhitungan secara manual dan data-data hasil simulasi. Pelaksanaan tugas akhir ini mengikuti diagram alir perancangan yang ditunjukkan pada Gambar 2.

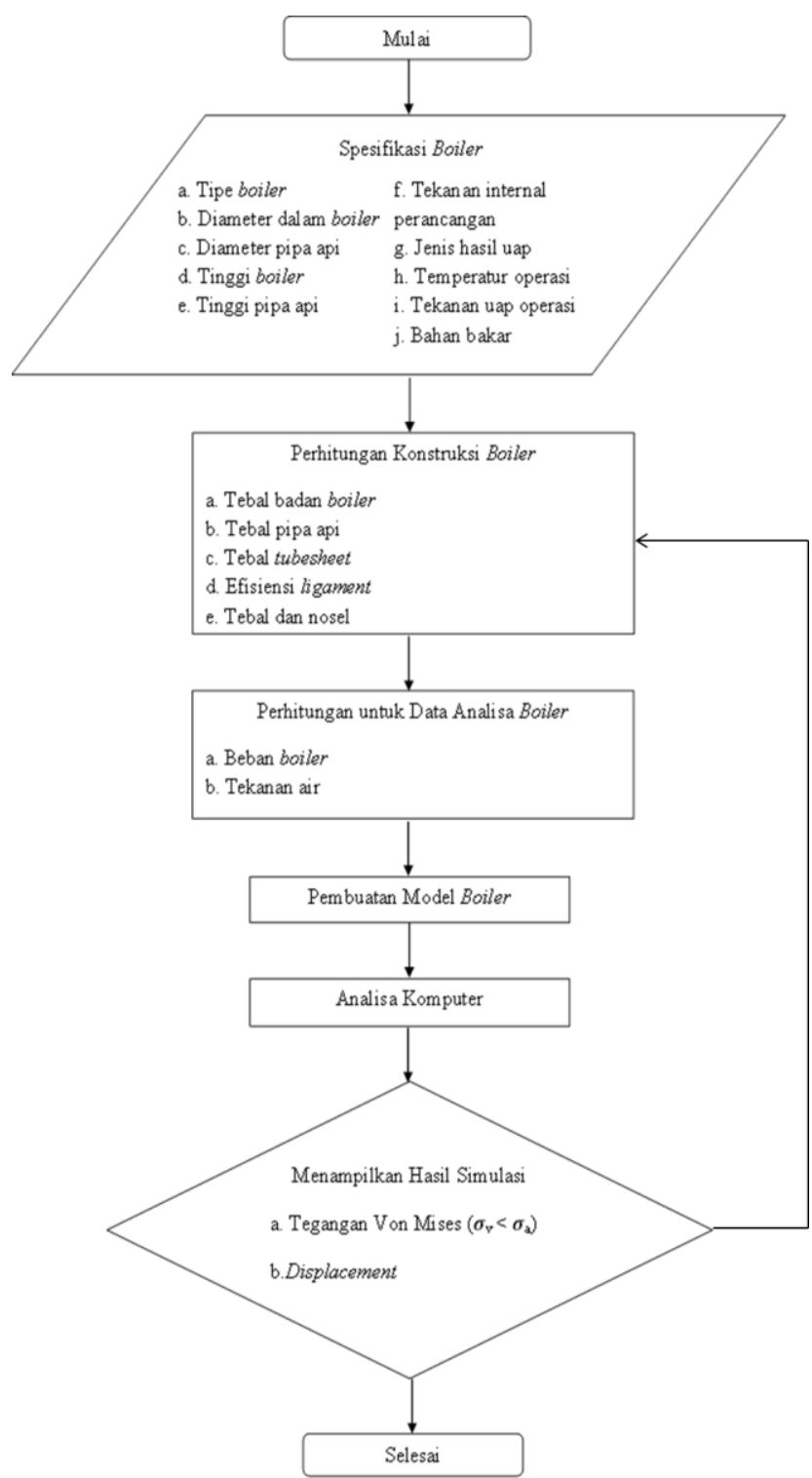

Gambar 2. Diagram Alir Perancangan

\section{HASIL DAN PEMBAHASAN}

Spesifikasi boiler yang dirancang mempunyai datadata sebagai berikut:
a. Tipe Boiler
: Vertical Firetube Boiler

b. Diameter Dalam Badan Boiler : $750 \mathrm{~mm}$

c. Diameter Pipa Api : $70 \mathrm{~mm}$ (Jumlah pipa

21 buah)

d. Tinggi Boiler $\quad: 1600 \mathrm{~mm}$

e. Tinggi Pipa Api : $1200 \mathrm{~mm}$

f. Tekanan Internal Perancangan : $6 \mathrm{Bar}$

g. Jenis Hasil Uap : Uap Jenuh

h. Temperatur Operasi $\quad: 100^{\circ} \mathrm{C}-150^{\circ} \mathrm{C}$

i. Tekanan Uap Operasi $\quad: 4$ Bar

j. Bahan Bakar : LPG (Liquified

Petrolium Gas)

A. Desain Boiler

Standar Perancangan : ASME Section IV

Material

Spesifikasi Material :

: SA - 285 Grade C

a. Maximum Allowable Stress Value (S) : $11 \mathrm{Ksi}=$ $11000 \mathrm{lb} / \mathrm{in}^{2}$ (ASME Section IV 2007)

b. Joint Coefficient (E) : $85 \%$ (ASME Section IV 2007)

Maka tebal minimum plat boiler yang diizinkan adalah:

$t=\frac{P \cdot R}{S \cdot E-0.6 P}$

dimana:

$\mathrm{t}=\quad$ Tebal dinding silinder yang dibutuhkan (inchi).

$\mathrm{P}=\quad$ Tekanan perancangan (design pressure) tidak kurang dari 30 psi (200 Kpa).

$\mathrm{R}=\quad$ Radius dalam silinder (inchi).

$\mathrm{S}=\quad$ Kekuatan stress maksimum material (maximum allowable stress) (psi).

$\mathrm{E}=\quad$ Efisiensi sambungan pada silinder.

maka:


$\mathrm{mm}$

B. Desain Pipa Api (Firetube)

Standar Perancangan

: ASME Section IV

Material

: SA - 53 Grade B

Spesifikasi Material :

a. Maximum Allowable Stress Value (S) : $12 \mathrm{Ksi}=$ 12000 lb/in2 (ASME Section IV 2007)

b. Yield Strength : 35 Ksi (ASME Section IV 2007)

Joint Coefficient (E) : 85 \% (ASME Section IV 2007

Perbandingan panjang dan diameter pipa api didapatkan dengan menggunakan rumus :

$$
\frac{L}{D^{0}}
$$

dimana:

$\mathrm{L}=$ Panjang pipa api $=1200 \mathrm{~mm}=47,244$ in

$\mathrm{D}^{\circ}=$ Diameter pipa api $=70 \mathrm{~mm}=2,7559 \mathrm{in}$

$\mathrm{t}=$ Ketebalan Boiler 
maka:

\section{$\frac{47,244 \text { in }}{2,7559 \text { in }}=17,1428$}

Untuk menentukan ketebalan pipa api ini, dilakukan metode trial and error yang proses perhitungannya adalah sebagai berikut:

Asumsi $\mathrm{D}^{\mathrm{o}} / \mathrm{t}=50$. Dari tabel $\mathrm{G}$ dan D ASME Section II Part D 2010 didapatkan data seperti pada Tabel 1 berikut ini:

Tabel 1. Pencarian Tekanan dengan $\mathrm{D}^{\circ} / \mathrm{t}=50$

\begin{tabular}{ccccccc}
\hline $\mathrm{D}^{\circ / \mathrm{t}}$ & $\mathrm{L} / \mathrm{D}_{\mathrm{0}}$ & Faktor A & $\mathrm{t}\left({ }^{\circ} \mathrm{C}\right)$ & Faktor A & $\begin{array}{c}\text { Faktor B } \\
(\mathrm{Mpa})\end{array}$ & $\begin{array}{c}\text { Faktor B } \\
\left(1 \mathrm{~b} / \mathrm{in}^{2}\right)\end{array}$ \\
\hline 50 & 12,000 & $4,49 \times 10^{-4}$ & 150 & $2,84 \times 10^{-4}$ & 27,90 & 4046,55 \\
50 & 14,430 & $4,46 \times 10^{-4}$ & 150 & $4,46 \times 10^{-4}$ & 43,81 & 6354,10 \\
50 & 16,000 & $4,44 \times 10^{-4}$ & 150 & $8,0 \times 10^{-4}$ & 78,60 & 11109,89 \\
\hline
\end{tabular}

Dari Tabel 1 digunakan untuk mencari nilai tekanan $(\mathrm{P})$, dengan syarat P > P1, dengan P1 sebesar 87,0226 lb/in ${ }^{2}$. Digunakan rumus:

$P=\frac{B}{D^{0} / t}$

dimana:

$\mathrm{P}=$ Tekanan $\left(\mathrm{lb} / \mathrm{in}^{2}\right)$

$\mathrm{B}=$ Faktor $\mathrm{B}\left(\mathrm{lb} / \mathrm{in}^{2}\right)$

maka:

$\frac{11109,89 \mathrm{lb} / \mathrm{in}^{2}}{50}=222,1978 \mathrm{lb} / \mathrm{in}^{2}$

Nilai ketebalan dari pipa api adalah:

$$
\begin{aligned}
& \frac{D^{\nu}}{t}=50 \\
& t=\frac{D^{\mathscr{V}}}{50}=\frac{70 \mathrm{~mm}}{50}=1_{x} 4 \mathrm{~mm}
\end{aligned}
$$

\section{Desain Tubesheet}

Tubesheet adalah tempat untuk menopang pipa - pipa api pada boiler. Tubesheet merupakan bagian yang mendapatkan tekanan yang paling besar.

Standar Perancangan : ASME Section IV

Material : SA - 285 Grade C

Spesifikasi Material :

a. Maximum Allowable Stress Value (S) : $11 \mathrm{Ksi}=$ $11000 \mathrm{lb} / \mathrm{in}^{2}$ (ASME Section IV 2007)

b. Joint Coefficient (E) : $85 \%$ (ASME Section IV 2007)

Dengan jarak maksimal antar pipa api adalah $120 \mathrm{~mm}$ (4,7244 in), maka tebal minimum plat boiler yang diizinkan adalah:

$\mathrm{t}=\sqrt{\left(\frac{D}{c s}\right)+\left(p^{2}-\frac{\pi D^{2}}{4}\right)}$

dimana:

$\mathrm{t}=$ Tebal dibutuhkan (inchi) .

$\mathrm{p}=$ Maksimal jarak antar pipa api (inchi).
$\mathrm{C}=2,7$ untuk pipa api pengelasan ketebalan kurang dari $11 \mathrm{~mm}(7 / 16$ inchi).

$\mathrm{C}=2,8$ untuk pipa api pengelasan ketebalan kurang dari $11 \mathrm{~mm}(7 / 16$ inchi).

maka:

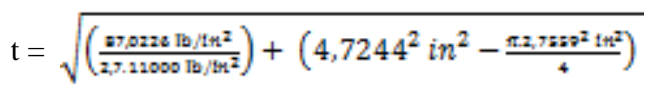

$\mathrm{t}=0,2321$ in $=5,8953 \mathrm{~mm}$, dibulatkan menjadi $6 \mathrm{~mm}$ $(0,2362$ in $)$.

\section{Efisiensi Ligament}

Ligament adalah jarak plat antar lubang pipa api pada tubesheet. Ligament menggunakan pola jarak yang sama pada setiap baris. Berikut merupakan proses perhitungan efisiensi dari ligament.

$E=\frac{p-d}{p}$

Dimana :

$\mathrm{E}=$ Efisiensi ligament .

$\mathrm{p}=$ Jarak antar lubang (inchi).

$\mathrm{d}=$ Diameter lubang pipa api (inchi).

Maka :

$E=\frac{4,2744 \mathrm{in}-2,7559 \mathrm{in}}{4,2744 \mathrm{in}}=0,4166=41,66 \%$

\section{E. Desain Nosel}

Pipa nosel berfungsi sebagai penopang instrumen boiler seperti safety valve, pressure gauge, thermometer, water level gauge, main steam valve dan blowdown.

Standar Perancangan : ASME Section IV

Material : SA - 53 Grade B

Spesifikasi Material :

a. Maximum Allowable Stress Value (S) : $12 \mathrm{Ksi}=$ $12000 \mathrm{lb} / \mathrm{in} 2$ (ASME Section IV 2007)

b. Yield Strength : $35 \mathrm{Ksi}$ (ASME Section IV 2007)

c. Joint Coefficient (E) : 85 \% (ASME Section IV 2007)

Rumus yang digunakan untuk mencari ketebalan pada nosel adalah :

$t=\frac{P \cdot R}{S \cdot E-Q_{2} \cdot P^{P}}+0,04$

dimana:

$\mathrm{t}=$ Tebal dinding silinder yang dibutuhkan (inchi).

$\mathrm{P}=$ Tekanan perancangan (design pressure) tidak kurang dari 30 psi (200 Kpa).

$\mathrm{R}=$ Radius dalam silinder (inchi).

$\mathrm{S}=$ Kekuatan stress maksimum material (maximum allowable stress) (psi).

$\mathrm{E}=$ Efisiensi sambungan pada silinder.

a. Pipa Nosel Safety Valve, pressure gauge, thermometer, dan water pressure gauge 
Pipa nosel menggunakan pipa carbon steel berdiameter 1 in. Maka tebal pipa nosel yang dibutuhkan adalah:

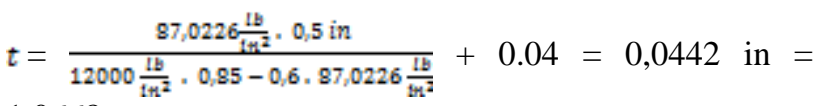
$1,0668 \mathrm{~mm}$

b. Pipa Nosel main steam dan blowdown

Pipa nosel menggunakan pipa carbon steel berdiameter 2 in. Maka tebal pipa nosel yang dibutuhkan adalah:

$t=\frac{97,0226 \frac{\mathbb{E}}{\mathrm{ft}^{2}} \cdot 1 \mathrm{in}}{12000 \frac{\mathbb{E}}{\mathrm{fH}^{2}} \cdot 0,85-0,6 \cdot 970226 \frac{\mathbb{E}}{\mathrm{H}^{2}}}+0.04=0,0485$ in $=$ $1,2319 \mathrm{~mm}$

\section{E. Perhitungan Beban}

Beberapa variabel yang dibutuhkan untuk mendapatkan beban pada boiler adalah sebagai berikut:

\begin{tabular}{|c|c|}
\hline Volume Badan Boiler & $\begin{array}{l}=\mathrm{V}_{\mathrm{badan} \text { boiler }}=\mathrm{L}_{\mathrm{b}} \cdot \mathrm{t}_{\mathrm{ba}} \\
=\Pi \cdot \mathrm{r}_{\mathrm{b}}^{2} \cdot \mathrm{t}_{\mathrm{ba}} \\
=\Pi \cdot 0,375^{2} \mathrm{~m}^{2} \cdot 1,15 \mathrm{~m} \\
=0,508 \mathrm{~m}^{3}\end{array}$ \\
\hline Volume Pipa Api & $\begin{array}{l}=\mathrm{V}_{\text {pipa api }}=\mathrm{L}_{\mathrm{t}} \cdot \mathrm{t}_{\mathrm{ta}} \\
=\Pi \cdot \mathrm{r}_{\mathrm{t}}^{2} \cdot \mathrm{t}_{\mathrm{ta}} \\
=\Pi \cdot 0,035^{2} \mathrm{~m}^{2} \cdot 0,75 \mathrm{~m} \\
=0,0028 \mathrm{~m}^{3}\end{array}$ \\
\hline Volume Pipa Api Total & $\begin{aligned}= & V_{\text {pipa api total }}=V_{\text {pipa api }} . \\
& \text { Jumlah pipa api } \\
= & 0,0028 \mathrm{~m}^{3} \cdot 21=0,0588 \mathrm{~m}^{3}\end{aligned}$ \\
\hline Volume Dapur & $\begin{array}{l}=\mathrm{V}_{\text {Dapur }}=\mathrm{L}_{\mathrm{d}} \cdot \mathrm{t}_{\mathrm{d}} \\
=\Pi \cdot \mathrm{r}_{\mathrm{d}}^{2} \cdot \mathrm{t}_{\mathrm{d}} \\
=\Pi \cdot 0,0335^{2} \mathrm{~m}^{2} \cdot 0,4 \mathrm{~m} \\
=0,141 \mathrm{~m}^{3}\end{array}$ \\
\hline Volume air & $\begin{aligned}= & V_{\text {air }}=V_{\text {badan boiler }}-\left(\mathrm{V}_{\text {pipa api }}\right. \\
& \left.\text { total }+\mathrm{V}_{\text {Dapur }}\right) \\
= & 0,508 \mathrm{~m}^{3}-\left(0,0588 \mathrm{~m}^{3}+\right. \\
& \left.0,141 \mathrm{~m}^{3}\right)=0,3082 \mathrm{~m}^{3}\end{aligned}$ \\
\hline
\end{tabular}

Maka beban pada boiler dapat ditentukan dengan menggunakan rumus :

Massa Air $\quad=\mathrm{m}_{\text {air }}=\mathrm{V}_{\text {air }} \cdot \rho_{\text {air }}$

$=0,3082 \mathrm{~m}^{3} .1000 \mathrm{~kg} / \mathrm{m}^{3}=308,2 \mathrm{~kg}=3082 \mathrm{~N}$

\section{F. Perhitungan Tekanan Air}

Beberapa variabel yang dibutuhkan untuk mendapatkan tekanan kerja pada boiler adalah sebagai berikut :

Luas Dinding Badan Boiler $=$ ח. $\mathrm{D}_{\mathrm{b}} . \mathrm{t}_{\mathrm{b}}$

$$
\begin{aligned}
& =\Pi \cdot 0,75 \mathrm{~m} \cdot 1,6 \mathrm{~m} \\
& =3,7699 \mathrm{~m}^{2}
\end{aligned}
$$

Luas Pipa Api Total = Luas Pipa Api . Jumlah Pipa Api

$$
\begin{aligned}
& =\Pi \cdot D_{t} \cdot t_{t} \cdot 21 \\
& =\Pi \cdot 0,07 \mathrm{~m} \cdot 1,2 \mathrm{~m} \cdot 21 \\
& =5,5417 \mathrm{~m}^{2} \\
& =\Pi \cdot D_{d} \cdot t_{d} \\
& =\Pi \cdot 0,65 \mathrm{~m} \cdot 0,4 \mathrm{~m} \\
& =0,8419 \mathrm{~m}^{2}
\end{aligned}
$$

Luas Dapur

Total Luas Permukaan

$$
\begin{aligned}
= & \text { Luas Dinding Badan Boiler } \\
& + \text { Luas Pipa Api Total }+ \\
& \text { Luas Dapur } \\
= & 3,7699 \mathrm{~m}^{2}+5,5417 \mathrm{~m}^{2}+ \\
& 0,8419 \mathrm{~m}^{2}=10,1535 \mathrm{~m}^{2}
\end{aligned}
$$

Maka tekanan kerja pada boiler dapat ditentukan dengan menggunakan rumus :

$$
\begin{aligned}
& \text { Tekanan Kerja }=\frac{M \text { air }}{\text { Total luas permukaan }} \\
& \text { Tekanan Kerja }=\frac{\frac{a 092 ~}{10}, 1585 \mathrm{~m}^{2}}{10,1503,5406 \mathrm{~N} / \mathrm{m}^{2}} \\
& \text { F. Analisis Statis Model Boiler }
\end{aligned}
$$

Analisis statis pada model boiler ini dilakukan dengan simulasi Application Mechania Analysis pada Pro Engineer Wildfire 4.0. Tabel 2 menunjukkan data-data yang akan diberikan pada model boiler:

Tabel 2. Load Desain Boiler

\begin{tabular}{lccc}
\hline No & Load & Besar Load & Bagian \\
\hline 1. & Beban & $3082 \mathrm{~N}$ & Tubesheet bagian bawah \\
2. & Tekanan & $303,5406 \mathrm{~N} / \mathrm{m}^{2}$ & $\begin{array}{c}\text { Permukaan Firetube dan permukaan dalam } \\
\text { dinding boiler }\end{array}$ \\
3. & Temperatur & $393 \mathrm{~K}$ & Semua bagian boiler \\
\hline
\end{tabular}

Temperatur yang bekerja pada boiler adalah temperatur pembakaran yaitu $150{ }^{\circ} \mathrm{C}(423 \mathrm{~K})$. Pada analisis software Pro Engineer Wildfire 4.0, temperatur disesuaikan dengan temperatur ruang yaitu diasumsikan temperatur ruang adalah $30{ }^{0} \mathrm{C}$. Maka temperatur yang diberikan pada boiler adalah $120{ }^{\circ} \mathrm{C}(393 \mathrm{~K})$.

Hasil proses analisis statis model boiler yang ditampilkan adalah tegangan Von Mises dan displacement. Gambar 3 dan Gambar 4 merupakan hasil dari analisis tersebut:

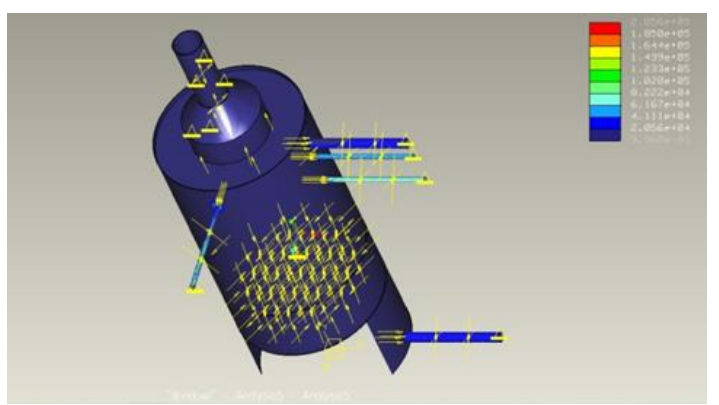

Gambar 3. Hasil Von mises Stress pada Model Boiler 


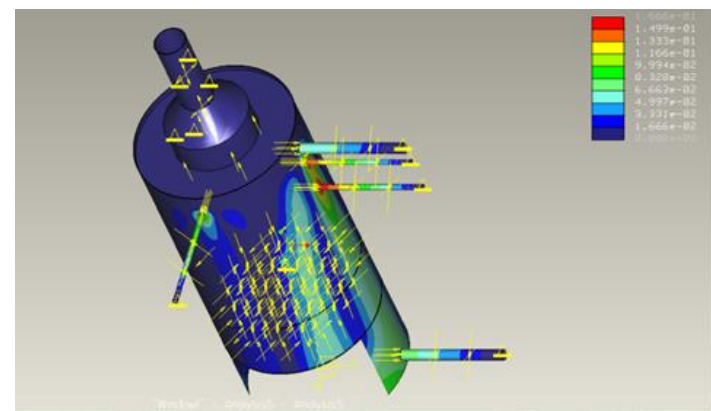

Gambar 4. Hasil Displacement pada Model Boiler

Setelah dilakukan analisis menggunakan software Pro Engineer Wildfire 4.0, maka dapat diketahui bahwa hasil analisis pada boiler ditampilkan pada Tabel 3 .

Tabel 3. Hasil Analisis Boiler

\begin{tabular}{cc}
\hline Karakteristik & $\begin{array}{c}\text { Hasil } \\
\text { Analisis }\end{array}$ \\
\hline Tegangan Von Mises Maksimal & $2,056 \times 10^{5} \mathrm{~kg} / \mathrm{mm} \cdot \mathrm{sec}^{2}=2,056 \times 10^{8}$ \\
$\mathrm{~N} / \mathrm{m}^{2}$
\end{tabular}

\section{KESIMPULAN}

1. Berdasar perhitungan konstruksi boiler, didapatkan data sebagai berikut:

a. Badan boiler:

- $\varnothing: 750 \mathrm{~mm}$,

- Tinggi: $1600 \mathrm{~mm}$,

- Tebal: 3,5077 mm

- Bahan: plat SA - 285 Grade C

b. Pipa api:

- $\varnothing: 70 \mathrm{~mm}$,

- Tinggi: $1200 \mathrm{~mm}$

- Tebal: 1,4 mm

- Bahan pipa: SA - 53 Grade B

c. Tubesheet:

- $\varnothing: 750 \mathrm{~mm}$

- Tebal: $6 \mathrm{~mm}$

- Jarak maksimal antar pipa api: $120 \mathrm{~mm}$

- Bahan: plat SA - 285 Grade C

d. Efisiensi ligament: 41,66\%

e. Pipa nosel safety valve, pressure gauge, thermometer, dan water pressure gauge:

- $\varnothing: 25,4 \mathrm{~mm}$

- Tebal: 1,0668 mm

- Bahan: plat SA - 53 Grade B

f. Pipa nosel main steam dan blowdown:

- $\varnothing: 50,8 \mathrm{~mm}$

- Tebal: $1,2319 \mathrm{~mm}$

- Bahan: plat SA - 53 Grade B

2. Dari hasil analisa statis model boiler secara keseluruhan dengan software Pro Engineer Wildfire 4.0, didapatkan data sebagai berikut:

a. Tegangan Von Mises maksimal: 2,056 x $10^{8} \mathrm{~N} / \mathrm{m}^{2}$ b. Tegangan Von Mises minimal: $9,960 \mathrm{~N} / \mathrm{m}^{2}$

c. Displacement maksimal: $1,666 \times 10^{-1} \mathrm{~mm}$

d. Displacement minimal: $0 \mathrm{~mm}$

\section{UCAPAN TERIMA KASIH}

Terima kasih kepada yayasan Teijin yang telah memberikan dana untuk melakukan penelitian ini.

\section{REFERENSI}

[1] Maharani, Peningkatan Efisiensi Produksi Baglog Melalui Percepatan Waktu Siklus Produksi di Usaha Lancar Abadi Pendekatan Critical Path Method, EJurnal Agribisnis dan Agrowisata, vol.5, no.1, 2016, pp. $1-10$.

[2] Suriawiria. U, Pengantar untuk Mengenal dan Menanam Jamur, Bandung, 1986.

[3] Roswati, Perancangan Boiler dengan Memanfaatkan Sampah Kering untuk Bahan Bakar PLTU Mini $3 \mathrm{~kW}$ STT-PLN, Jurnal Power Plant, vol.5, no.1, 2017, pp. 1 -10 .

[4] Yusuf. Y dan Budi. S, Analisa Perbandingan Pemakaian Bahan Bakar Solar Fuel Oil (SFO) dan Liquefied Natural Gas (LNG) Terhadap Kinerja Boiler di Unit Cold Rolling Mill (CRM) Di PT X, Jurnal Teknika, vol.12, no.3, 2016, pp. 439 - 446.

[5] Raharjo. W.D dan Karnowo, Mesin Konversi Energi, Semarang, 2008.

[6] Jhonas. P, Perancangan Boiler Pipa Api untuk Perebusan Bubur Kedelai pada Industri Tahu Kapasitas Uap Jenuh $160 \mathrm{Kg} / \mathrm{Jam}$, Jurnal Teknik Mesin, vol.2, no.1, 2016, pp. $1-8$.

[7] Desai. C.S, Dasar-Dasar Metode Elemen Hingga, Jakarta, 1996. 